\title{
Isothermal Temper Embrittlement of SAE 3140 Steel
}

\author{
by F. L. Carr, M. Goldman, L. D. Jaffe, and D. C. Buffum
}

$\mathrm{T}$ an earlier investigation by Jaffe and Buffum, ${ }^{1}$ a 1 time-temperature transformation diagram for isothermal temper embrittlement of an SAE 3140 steel showed some suggestion of two overlapping "noses." These authors mentioned, as a possible explanation, that their specimens embrittled at $525^{\circ} \mathrm{C}$ were slightly softer than expected, perhaps because of some slight unknown variation in tempering treatment. Because a double nose would be of considerable importance in elucidating the mechanism of the temper brittleness reaction, ${ }^{2}$ it appeared worthwhile to redetermine the portion of the diagram near $525^{\circ} \mathrm{C}$.

The same heat of SAE 3140 steel was used as in the previous work, and experimental procedures were the same. ${ }^{1}$ Blanks were austenitized $1 \mathrm{hr}$ at $900^{\circ} \mathrm{C}$, water-quenched, tempered $1 \mathrm{hr}$ at $675^{\circ} \mathrm{C}$, and water-quenched. Groups were then embrittled isothermally at the temperatures and for the times

Table I. Transition Temperatures, ${ }^{\circ} \mathrm{C} .100$ Pct Fibrous Criterion

\begin{tabular}{|c|c|c|c|c|c|}
\hline \multirow{2}{*}{$\begin{array}{c}\text { Em- } \\
\text { brittling } \\
\text { Tempera- } \\
\text { ture, }{ }^{\circ} \mathbf{C}\end{array}$} & \multirow[b]{2}{*}{$5 \overline{M i n}$} & \multicolumn{3}{|c|}{ Embrittling Time } & \multirow[b]{2}{*}{$48 \mathrm{Hr}$} \\
\hline & & 20 Min & 11/2 Hr* & $8 \mathrm{Hr}$ & \\
\hline $\begin{array}{l}450 \\
475 \\
500 \\
525 \\
550 \\
575\end{array}$ & $\begin{array}{l}-68 \\
-70 \\
-73 \\
-65 \\
-68 \\
-71\end{array}$ & $\begin{array}{l}-70 \\
-68 \\
-74 \\
-65 \\
-63 \\
-60\end{array}$ & $\begin{array}{l}-70 \\
-68 \\
-65 \\
-46 \\
-52 \\
-59\end{array}$ & $\begin{array}{l}-69 \\
-55 \\
-38 \\
-24 \\
-38 \\
-54\end{array}$ & $\begin{array}{l}-50 \\
-20 \\
+2 \\
-18 \\
-42 \\
-54\end{array}$ \\
\hline \multirow{2}{*}{$\begin{array}{c}\text { Temper- } \\
\text { ing } \\
\text { Tempera- } \\
\text { ture, }{ }^{\circ} \mathbf{C}\end{array}$} & \multicolumn{5}{|c|}{ Tempering Time } \\
\hline & $1 \mathrm{Hr}$ & $4 \mathrm{Hr}$ & $16 \mathrm{Hr}$ & $48 \mathrm{Hr}$ & $240 \mathrm{Hr}$ \\
\hline 675 & -80 & $\begin{array}{c}-68 \\
(\operatorname{Rc} 21) \dagger\end{array}$ & $\begin{array}{c}-57 \\
\left(\operatorname{Re} 19^{1 / 2}\right)\end{array}$ & $\left(\begin{array}{c}-42 \\
\left(\operatorname{Rc} 15^{1 / 2}\right.\end{array}\right)$ & $\begin{array}{c}-20 \\
(\operatorname{Rc} 10)\end{array}$ \\
\hline
\end{tabular}

* This time is the average of treatments of $1 \mathrm{hr} 20 \mathrm{~min}$ and $1 \mathrm{hr}$

40 min.

shown in Table I, and water-quenched. For comparison, one series was tempered various times at $675^{\circ} \mathrm{C}$, water-quenched, and given no further treatment. V-notched Charpy impact specimens machined from the blanks were tested over a range of temperatures. Energy absorption and percentage of fibrous fracture were plotted vs test temperature for each group, utilizing both the new data and those for the same treatment obtained in the earlier work, ${ }^{1}$ except that the earlier data at $525^{\circ} \mathrm{C}$ were discarded.*

\footnotetext{
* One of the embrittling times used in this study was $1 \mathrm{hr} 20$ min; the corresponding time in the previous work was $1 \mathrm{hr} 40$ min. Both sets of data were plotted together. The time of " 4 min"
} listed in the earlier paper should have read " 5 min."

Hardnesses of all groups were between Rockwell C22 and $\mathrm{C} 25$, except where indicated in the table.

From the graphs mentioned, temperatures of transition from tough to brittle failure were read, and

F. L. CARR, associated with National Research Corp., Cambridge, Mass., and M. GOLDMAN, associated with Goodyear Aircraft Corp., Akron, Ohio, were formerly with Watertown Arsenal, and L. D. JAFFE and D. C. BUFFUM, Members AIME, are associated with Watertown Arsenal, Watertown, Mass.

TN 165E. Manuscript, April 3, 1953.

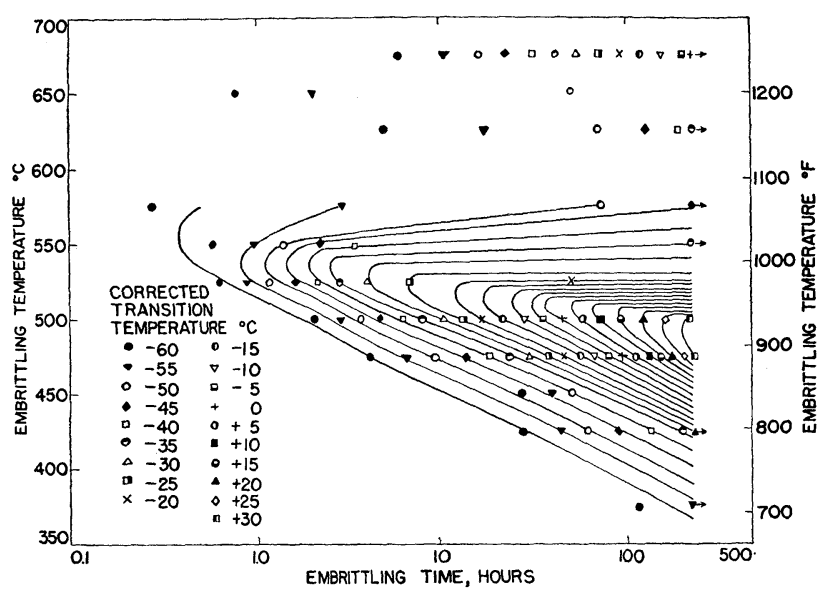

Fig. 1-Time-temperature diagram for temper embrittlement of SAE 3140 steel.

are given in Table I. After a small correction $\left(-0.28^{\circ} \mathrm{C} / \mathrm{BHN}\right)$ for the variation of hardness ${ }^{3}$ from Rockwell $\mathrm{C} 24$, the transition temperatures were plotted against embrittling time for each embrittling temperature, using the data of Table I for the range of treatments covered there, and using previous data ${ }^{1}$ for other treatments. By cross-plotting, Fig. 1 was finally obtained. It appears from this figure that if there are two noses to the time-temperature-transformation diagram for isothermal temper embrittlement of SAE 3140 steel, the upper nose must lie above $575^{\circ} \mathrm{C}$.

As interest had been primarily in the region near $525^{\circ} \mathrm{C}$, a thorough study of embrittlement above $575^{\circ} \mathrm{C}$ was not made. Fig. 1 shows that such a study is needed, especially since preliminary measurements at the tempering temperature of $675^{\circ} \mathrm{C}$ reveal much more rapid embrittlement than would be expected from the data at lower temperatures. The transition temperature increased, approximately, as the logarithm of the tempering time (about $81 / 2{ }^{\circ} \mathrm{C}$, after correction for hardness, for each doubling of the time). ${ }^{4}$ Since three tensile specimens tempered 240 $\mathrm{hr}$ at $675^{\circ} \mathrm{C}$ and water-quenched had an average yield-tensile ratio of 0.844 , with 70.7 pct reduction of area, it is assumed ${ }^{1}$ that the tempering temperature is not above $A e_{1}$. The omission of a quench-andreheat operation below $A e_{1}$ for the groups tempered at $675^{\circ} \mathrm{C}$, as compared to groups embrittled at lower temperatures, should not affect results. ${ }^{5}$

More detailed investigation of embrittlement above $575^{\circ} \mathrm{C}$ is now under way.

\section{References}

${ }^{1}$ L. D. Jaffe and D. C. Buffum: Isothermal Temper Embrittlement. Trans. ASM (1950) 42, pp. 604-614.

${ }^{2}$ M. Baeyertz: Discussion to ref. 1. Trans. ASM (1950) 42, pp. 614-615.

${ }^{3}$ D. C. Buffum and L. D. Jaffe: Effect of Hardness on Temper Brittleness. Trans. AIME (1951) 191, p. 540; Journal OF METALS (July 1951).

${ }^{4}$ L. D. Jaffe and D. C. Buffum: Retrogression of Temper Brittleness. Revue de Metallurgie (1951) 48, pp. 609-612.

${ }^{5}$ L. D. Jaffe, D. C. Buffum, and F. L. Carr: Effect of Various Heat Treating Cycles upon Temper Brittleness. Trans. ASM (1953) 45, pp. 725-731. 